\title{
How QUALIS CAPES influences Brazilian academic production? A stimulus or a barrier for advancement?
}

Como o sistema QUALIS CAPES influencia a produção acadêmica brasileira? Um estímulo ou uma barreira para o avanço?

GUSTAVO ANDREY ALMEIDA LOPES FERNANDES* LEONARDO DE OLIVEIRA MANCHINI**

RESUMO: Este estudo investiga as consequências (RESULTADOS?) do QUALIS CAPES. Para tanto, são coletados dados sobre os conselhos editoriais das revistas classificadas como A1 e A2 nas áreas de Administração, Contabilidade e Turismo; e Economia. Os resultados mostram que os EUA e o Reino Unido dominam a produção acadêmica. O Brasil e outros países emergentes não são relevantes. Foram analisadas as questões dos cinco principais periódicos de cada área, mostrando que o QUALIS pode direcionar a pesquisa no país para questões não relacionadas às questões brasileiras.

PALAVRAS-CHAVE: Desenvolvimento; política governamental; pesquisa.

ABSTRACT: This study delves into the consequences of QUALIS CAPES. To do that, data on the editorial boards of the journals classified as A1 and A2 in the areas of Business, Accounting and Tourism; and Economics are collected. Findings show that the US and the UK dominate the academic production. Brazil and other emerging countries are not relevant. Issues of the five top journals of each area were analyzed, showing that QUALIS may bias research in the country to issues not connected to Brazilian questions.

KEYWORDS: Development; government policy; research.

JEL Classification: O3; O38.

\section{INTRODUCTION}

Journals are valuable assets for the academic community. Publishing in a prestigious venue leads to recognition among peers and contributes to guide the direc-

\footnotetext{
* Professor da Escola de Administração e Economia de São Paulo da Fundação Getulio Vargas - EAESP/ FGV, São Paulo/SP, Brasil. E-mail: Gustavo.fernandes@fgv.br.

** Pesquisador de Administração Pública da Escola de Administração e Economia de São Paulo da Fundação Getulio Vargas - EAESP-FGV, São Paulo/SP, Brasil. E-mail: leoomanchini@gmail.com. Submitted: 9/October/2018; Approved: 26/October/2018.
} 
tion scientific knowledge will take. However, the relevance of scientific journals is not a neutral issue. It has political content. Usually, relevance is mostly defined by the position in international databases. CAPES, the Brazilian agency for the evaluation of research uses them as source of academic evaluation. The way this system works is a paramount question since it influences every purpose of the scientific community. Brazilian scholars are subject to rules that lead them to publish according to the standards set by CAPES. The set of rules is called QUALIS and is defined every three years.

The relevance of a journal is derived from its position on international databases. That gives them recognition or invisibility. Consequently, scholars are also subject to it, seeking to publish in journals with give them more visibility to their research. At the same time, they usually have to meet goals imposed by the institution they are affiliated.

The objective of this paper is to understand how the national evaluation system influences Brazilian academic production. To do that, we delve into who are editors of the more respected journals by the Brazilian evaluation system. We also investigate if requirements of quality may represent a barrier for advancement of Brazilian journals. For example, how balance the US hegemony in the editorial boards and Brazilian research interests without making local American problems look like they were universal? Research concerning development, for instance, is a good example. Would be feasible to publish in a European journal research that leads to policies not meeting European interests? That is not a small question. Given that: does CAPES take into account all these aspects when establishing national scientific standards? If not, what are the consequences? We also discuss barriers that prevent Brazil from reaching a global role in the academic scene.

This paper also deals with a large literature concerning the assessment of scientific production. When comparing national and international journals, Almeida (2010) found that Brazilian publications tend to be focused on research, while international ones have room for teaching and extension. Brazilian journals are mostly published in Portuguese and are maintained by higher education institutions, while those especially from the English-speaking world, only accept submissions in English (96\%) and are established by professional publishers. National journals have been mostly established in recent years, with the majority created between 1995 and 2004, while foreign journals are older and were consolidated around the 1980s.

The paper is organized in six sections. After this brief introduction, the way Brazilian scientific evaluation system is outlined. Next, the methodology is exposed. Results are showed with respect to which are the most influential journals and who is behind them. In the fifth section we discuss who exert dominance in the Brazilian research arena followed by our conclusions. 


\section{HOW BRAZILIANS EVALUATE SCIENTIFIC PRODUCTION}

The Brazilian Research Agency (CAPES) was created in 1951 (Passos, 2011; Pereira, 2005). The relevance of CAPES as a promoter of scientific production is undeniable as it is responsible for the Brazilian evaluation system, which is known as QUALIS. Journals where researchers affiliated to Brazilian universities publish are classified into eight categories (A1, A2, B1, B2, B3, B4, B5, C). No matter which field, a simple rule has always to be followed: the number of A1 publications has to be smaller than the number of journals in the $\mathrm{A} 2$ group and the sum of the two cannot exceed $26 \%$ of the total; A1 + A2 + B1 cannot be more than $50 \%$ of the total.

The number of citations and influence in academic productions are the main drivers of the whole QUALIS system. Indexing systems such as ISI (International Scientific Indexing), Scopus and WoS (Web of Science) in the international context, and Scielo in Latin America (CAPES, 2016) are used to measure impact.

Scopus analyses many aspects of a journal to assess impact. The political aspect is about having a clear editorial policy, peer review and diversity regarding geographic distribution of both editors and authors. The content category concerns the journal's academic contribution to the field, the quality of abstracts, among other issues. Relevance is measured by the citations of the articles on the journals in the index and also by the importance of the editors. Regularity of publications is also taken into account as well as online accessibility (Elsevier, 2016).

The International Scientific Indexing (ISI) maintained by Thomson Reuters, also uses categories similar to those observed in the Scopus indexation service. Quality is measured mostly according to the number of citations papers published in the journal have. Some other aspects are relevant such as relevance in the field, observance of technical norms in the manuscripts, clarity of the website and the presence of the journal in international markets, among other items. Editorial quality is also taken into account, which implies providing detailed information on editorial lines, editorial board members, and information such as addresses, ISSN (International Standard Serial Number), and frequency. The English language is preferred for the measurement of such category (ISI, 2016).

According to Fausto (2016), WoS is extremely careful to index papers. The criteria for journal indexing are divided into four areas. The first is related to norms of publication, requiring: peer review; ethical conduct, not presenting predatory publication or excessive self-citation; specific format; frequency in publications; international publishing conventions; texts in English. The second area is editorial content, where WoS determines whether the journal content is relevant and adds something to the database. The third is the international focus, looking for journals with broad scope, not only regional, with an internationally diverse board focused on global issues. The last criterion is the analysis of citations, which seeks to measure the publications' impact and their academic contribution (THOMSON REUTERS, 2016).

All of the bases above (Scopus, ISI, and WoS) value the English language, 
while ISI and WoS also pay attention presence and weight in the international market. Thus, journals from countries with less global relevance have an extreme disadvantage compared to European countries, such as United Kingdom and Germany, and North American countries, such as the United States and Canada. The relevance factor can be considered as subjective, since issues that are significant for Brazil may not be of equal importance for the most influential countries in the world.

Based on these worldly accepted indexes, CAPES establishes customized ranking for the most important groups of fields of knowledge. However, despite this common base, the way specialized ranking are defines may differ considerably.

\section{Business, Accounting and Tourism}

The field of Business, Accounting, and Tourism in QUALIS journals uses additional criteria to journal indexing databases. During the period 2013-2016, for a journal to be classified as A1, it had to have ISSN (the journal's international register), publish at least two issues per year and present h-index higher than 24 in the Scopus database or JCR impact factor (Journal Citation Reports) by Thomson Reuters higher than 1.4. Besides being indexed in databases, the journal must be specialized in the area. If it does not meet all those requirements, it will be classified as A2 (CAPES, 2015; ISSN, 2016).

The h-index represents the number of articles in a journal $(\mathrm{h})$ that received that same number $(\mathrm{h})$ or more citations in the scientific production present in the Scopus database. The JCR impact factor is calculated by the number of citations received in a year divided by the number of articles published in the journal over the same period. The Web of Science (WoS) database is used to calculate the impact factor (Elsevier, 2014; Thomson Reuters, 2016).

The requirement for classification A2 and B2 is the same, but the result of the indices may be lower. For A2, h-index in Scopus has to be equal to or lower than 24 and higher than 9, or the JCR impact factor is lower than or equal to 1.4 and higher than 0.7. When the indices are below the determinants for the classification $\mathrm{A} 2$, the journal is considered as B1.

To be classified as B2 to B5 the minimum requirements are: to have the ISSN and at least two editions per year. A maximum of a one-year delay is accepted for a journal classified as B5 to be published. Those classified in B2 must be edited by one of the following publishers: Sage; Elsevier; Emerald; Springer; Inderscience; Pergamo; Wiley; Routledge; Taylor and Francis. There is also the possibility of having an index lower than 0.1 in FI-Scielo or higher if the journal is in another area.

Journals that are considered the most relevant for the area are classified into a stratum above what would be classified by regular criteria. This is the case of the Revista de Administração Pública (RAP), which received level A2, instead of B1. The idea is to stimulate and boost the academic production in highly relevant but rarely addressed topics (CAPES, 2015). 


\section{Economics}

To understand the QUALIS CAPES evaluation in the area of Economics, it is necessary to look at the classification of the period 2010-2012. The journals of the area were evaluated based on the impact factors of the article by Combes and Linnemer (2010). The journals of other areas were evaluated considering the classification obtained in other areas of knowledge, establishing two ceilings: A2 for international and B2 for national journals. Nature, for example, is A2. The evaluation committee decided to classify as B1 the journals of the area of Economics that were considered B2 when they presented CLh and/or SJR and/or JCR impact factors and/ or registered in the SciELO database. Consolidated journals that were linked to graduate programs in Economics, with up-to-date publication and indexed in other databases, were promoted to B2, B3, B4, if they were B3, B4, B5, respectively.

In the last QUALIS CAPES evaluation period (2013-2016), the system maintained the classification of the journals that were considered as A1 to B4. As for those that had not yet been classified, the same criteria was applies following Combes and Linnemer (2010), JCR impact factor (also used for the area of Administration, Accounting and Tourism) and SJR, in addition to maintaining the ceiling as A2 and B2 for journals from other areas.

The impact factors established by Combes and Linnemer (2010) use a variety of data to build a formula that covers the peculiarities of the area of Economics. Interestingly, a journal to be evaluated must be linked both to the JCR statistical base (Thomson Reuters) and the EconLit (database related to the American Economic Association), which excludes a considerable part of the production that is linked to JCR, but not to EconLit, for example.

Anyway, the Economics area of QUALIS is considerably more rigid, having almost no space to non-specialized journals. The ceiling created for journals from other areas shows a preference for foreign journals, which can be classified as A2 at most, while nationals cannot exceed B2. Brazilians have succeeded to publish in 15 A1 level journals, all of which are foreign, and among the 47 classified in A2, only one of them is national.

Given this brief review of the Brazilian scientific evaluation system our research question can be stated clearly: how the national evaluation system influences Brazilian academic production? To answers that we split our main question into two auxiliary ones: Given the QUALIS rules, who are the ones who influence the directions Brazilian social science will follow? Secondly and not less importantly, does it bias scientific production towards addressing national needs?

\section{METHODOLOGY}

To address our research question, we use an exploratory approach using the list of all journals classified by CAPES in Economics, Business, Accounting and Tourism. We focus on these fields since they ground public policies set up to de- 
velop the country. As QUALIS defines a group of top journals, we delve into who are behind them. Data on the editorial boards of academic journals is collected. The editors (including associates ones) of journals classified in category A1 of the QUALIS CAPES 2014 system in the areas of Business, Accounting and Tourism; and Economics were listed including the information about the educational institution to which they belong and the country of the journal, except in the rare cases when the journal's publisher does not provide the data. The publishers who are not educational institutions were listed separately. All data was collected from the websites of the journals. The sum of all editors resulted in 5,758 individuals from different parts of the world and different institutions.

To analyze the journals classified as A2 in the same two areas, we listed the chief editors, according to their relevance, as well as the educational institution they belong to and their country. In the area of Economics, 72 editors from 43 journals were listed; in the area of Business, Accounting, and Tourism 177 from 139 journals. The publications' country of origin was also taken into account, as well as the hindex in SCImago.

Based on the data collected, the frequency of each country and educational institution in the editorial board was assessed. The nationality of the journals allowed us to observe their most recurrent locations. The h-index is used to evaluate the journals' performance, identifying the mean, median, amplitude and standard deviation of the journals, separating them by area (Business, Accounting and Tourism, and Economics) and by classification (A1 and A2).

The issues published by the five journals with higher h-index in each of the two areas were analyzed. All 906 articles published in the year 2016 and available in the journals' online portals were listed and classified in 12 categories (United States; BRICS; Brazil; Europe; Africa; Asia; Latin America; Development; Inequality; Health; Education; Theoretical). To fit each article into the appropriate categories, the topics named in the abstracts were considered as a representation of the article. It should be noted that the same article could be classified in more than one category.

Finally, the research used data provided by the World Bank for the year 2016 when referred to the variables 'per capita income' and 'population' of the countries: South Africa, Germany, Brazil, Canada, China, South Korea, the United States, France, Netherlands, India, Japan, the United Kingdom, and Russia. These two variables were used to establish a correlation with the editorial frequency and frequency of journals in each country.

\section{RESULTS}

\section{The Journals}

\section{Editors}

Because the conditions for the classification in the QUALIS CAPES 2014 categories are different for each of the areas, the number of A1 level journals is sig- 
nificantly lower in Economics (15 journals) while in Business, Accounting and Tourism, there are 68 A1 journals.

The hegemony of the US is impressive. Of the 5,046 editors listed, who belong to journals classified as A1 by QUALIS CAPES 2014 in the area of Business, Accounting and Tourism, 2,011 are related to institutions of the United States of America, corresponding to $39.8 \%$ of the editors in the area, as shown in Chart 1 . In the area of Economics, of 783 editors of A1 journals, 372 individuals are related to US institutions, showing even greater participation (53\%), as shown in Chart 2. The United Kingdom also showed relevance in the two areas, with 694 editors in Business, Accounting and Tourism (13.7\%), and 97 editors of journals in the area of Economics (13.8\%). It is important to note that in the area of Economics the institution and the country of origin of 81 editors were not identified, and this number was unconsidered.

The Brazilian participation in the area corresponds to $0.634 \%$ of the total number of editors, while in Economics the participation is $0.28 \%$. In both cases, it is not significant. Of the Brazilian institutions, Fundação Getulio Vargas and the University of São Paulo are the ones with more editors.

Chart 1: Editors' institutional origin: Administration, Accountancy, and Tourism - A1
Chart 2: Editors' institutional origin: Economics - A1

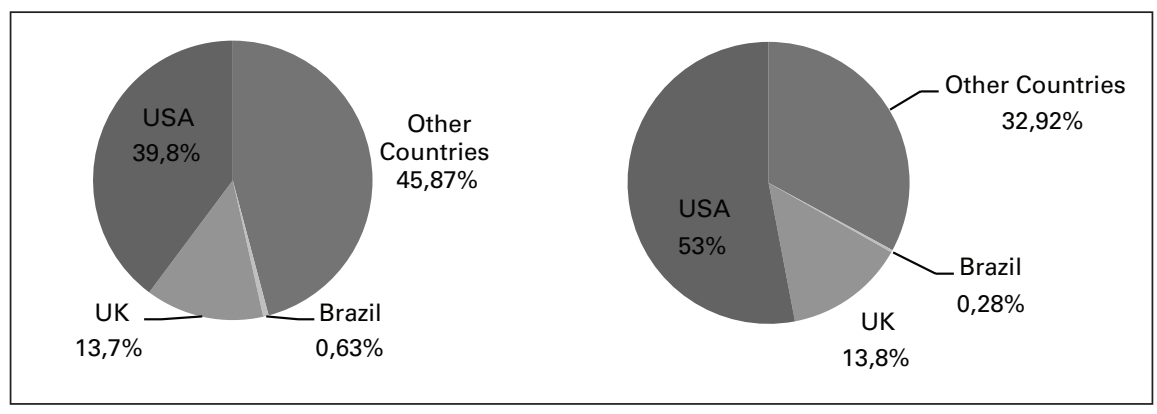

As for the A2 journals, the chief editors of the two areas were listed, representing the publications' editorial boards, based on their influence and discretion within the journals. There were 177 listed editors from 139 journals in the area of Business, Accounting and Tourism (Chart 3 ) and 72 from 43 journals (Chart 4) in Economics.

In Business, Accounting and Tourism the presence of the US is not as prominent as in the A1 journals, representing only $31.64 \%$ of the editors, while the participation of the United Kingdom grows to $19.77 \%$, revealing a more balanced influence between these two countries. In the area of Economics, there were $43.05 \%$ of editors from the US, while only $8.34 \%$ of editors were linked to educational institutions in the UK, which means that in Economics, the condition found in the A1 journals are reproduced for the publications classified as A2, with the hegemony of the United States.

Because there are more Brazilian journals in the A2 classification, the number 
of editors from Brazil grows in Business, Accounting and Tourism. Also, these editors are the chief editors of the journals, which reveal growth in the Brazilian influence. The Brazilian participation is of $8.47 \%$, against the almost inexistent $0.63 \%$ observed in the A1 publications. On the other hand, the area of Economics continues with reduced space for Brazilian topics and scholars, with participation of only $1.4 \%$, which is, as in the case of A1 journals, far from being significant.

Chart 3: Editors' institutional origin:

Administration, Accountancy, and Tourism - A2

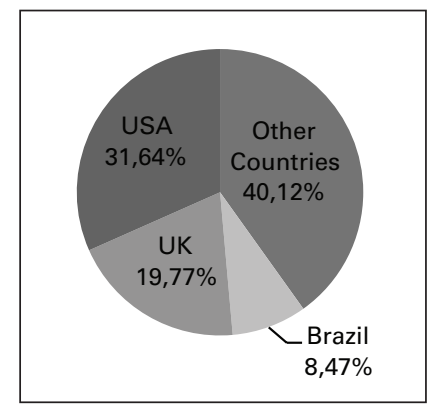

Chart 4: Editors' institutional origin: Economics - A2

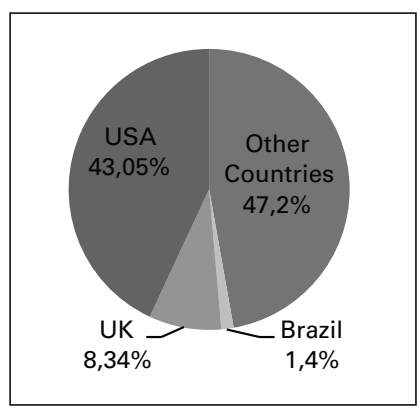

\section{Origin}

Before analyzing the journal's nationality, it is necessary to mention that journals that appear twice in the same classification and area because they are published in both online and printed versions were counted only once. The origin of the A1 journals in the area of and Business, Accounting and Tourism is represented by only four countries: The United States (19.7\%); United Kingdom (68.2\%); Netherlands $(10.6 \%)$; and Canada $(1.5 \%)$, according to Chart 5, highlighting greater British participation, although most of the editors are American. In the area of Economics, there are only three origins with similar participation: United States (42.86\%); United Kingdom (28.57\%); and the Netherlands $(28.57 \%)$ as it can be seen in Chart 6 . 
Chart 5: Journals' origin:

Administration, Accountancy, and Tourism - A1

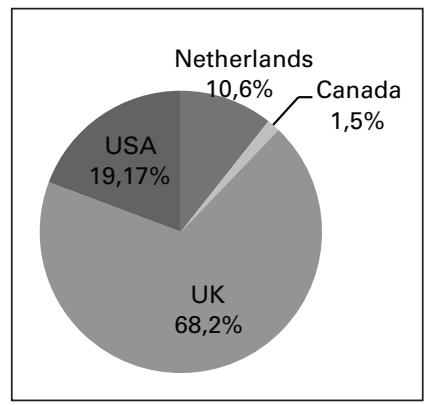

Chart 6: Journals' origin:

Economics - A1

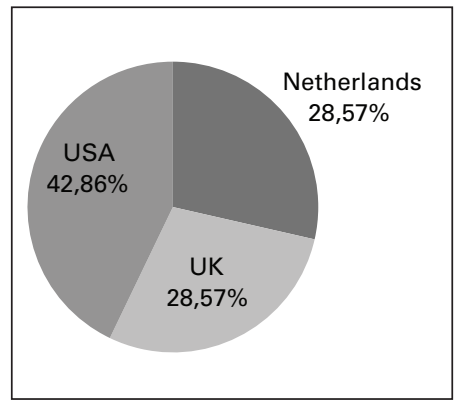

The A2 journals in the area of Business, Accounting and Tourism are located in several countries, such as the United Kingdom (37,6\%); United States $(24 \%)$; Netherlands (19.2\%); Brazil (9.6\%), as shown in Chart 7. Compared with the A1 publications, the United Kingdom loses relevance and opens space for the American, Dutch and, mainly, Brazilian journals. It is possible to register a variety of topics among the A2 journals, with publications focused on medicine, psychology, and social sciences, for example, differing from the A1 journals. In Economics, 36.6\% of the journals are from the United Kingdom, 34.15\% from the Netherlands, $21.95 \%$ from the United States, $4.88 \%$ from Germany, and 2.44\% from Brazil (with only one journal) as it is depicted in Chart 8 . 
Chart 7: Journals' origin:

Administration, Accountancy, and Tourism - A2

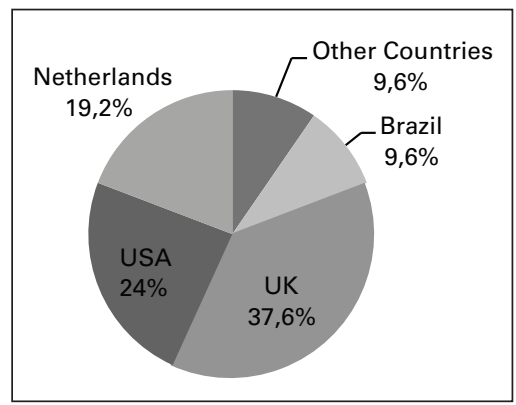

Chart 8: Journal's origin:

Economics - A2

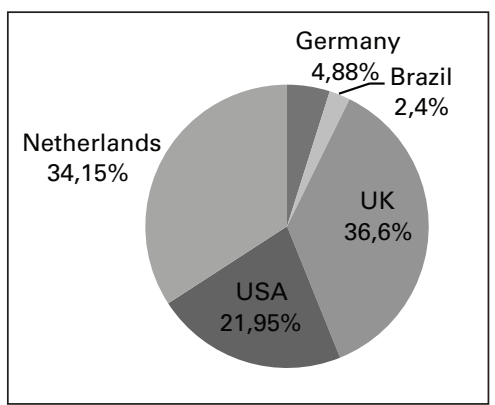

\section{Editors $\mathrm{x}$ Origin}

Next, we compare the location of the editors' institutions and the journals' origins. In the A1 journals of Business, Accounting and Tourism, it is found that $1,468(29.1 \%)$ of the 5,046 editors are related to institutions that are located in the journals' country of origin, being $861(17.06 \%)$ from the United States and 534 $(10.6 \%)$ from the United Kingdom. As for the A2 journals, there were $14(7.9 \%)$ editors of Brazilian journals related to Brazilian institutions, 21 (11.86\%) Americans related to institutions of the United States, and $25(14.12 \%)$ British editors related to institutions from the UK. There were $70(39,5 \%)$ editors out of a sample of 177 .

In the area of Economics, the journals classified as A1 showed that 199 $(25.4 \%)$ of the 783 editors come from an institution and journal that are in the same locality, being 146 (18.64\%) American and 56 (7.15\%) British. As for the journals classified as A2, only 15 editors show the same situation, nine $(60 \%)$ from the United States and one (6.7\%) from Brazil. 


\section{More Influent Universities}

Based on the number of editors in the several different institutions around the world, a ranking was prepared per area of knowledge and classification of the journals (A1 or A2) to uncover which universities have more scholars related to journals and, consequently, more influence in the world intellectual landscape. The list shows the name of the university, country, and percentage of the participation of scholars among the total number of editors listed in the research.

\section{Business, Accounting and Tourism - A1}

1. University of California (USA) $-0.971 \%$

2. The University of Texas at Austin (USA) - 0.891\%

3. Texas A\&M University (USA) $-0.773 \%$

4. Indiana University (USA) $-0.674 \%$

5. The Hong Kong Polytechnic University (China) $-0.654 \%$

6. Monash University (Australia) - 0.614\%

7. The University of Manchester (UK) $-0.594 \%$

8. University of Massachusetts (USA) $-0.575 \%$

9. The Ohio State University (USA) $-0.575 \%$

10. Arizona State University (USA) $-0.575 \%$

\section{Business, Accounting and Tourism - A2}

1. University of California (USA) $-2.82 \%$

2. University of London (UK) $-2.26 \%$

3. The University of Texas at Austin (USA) $-2.26 \%$

4. University of Cambridge (UK) $-1.69 \%$

5. Arizona State University (USA) $-1.69 \%$

6. Seoul National University (South Korea) - 1.69\%

7. Fundação Getulio Vargas (Brazil) - 1.69\%

In the A1 journals, of the 20 ranked universities, 15 are from the United States, with the four best also placed in the United States. In the A2 journals, there is a better balance with the presence of Brazilian institutions, such as the Fundação Getulio Vargas, which shares the fourth position with three other universities.

\section{Economics - A1}

1. University of California (USA) $-4.58 \%$

2. Northwestern University (USA) $-2.8 \%$

3. Stanford University (USA) $-2.55 \%$

4. New York University (USA) $-2.3 \%$

5. University of Pennsylvania (USA) $-2.04 \%$ 
6. Duke University (USA) $-1.9 \%$

7. Yale University (USA) $-1.66 \%$

8. Institute of Statistical Mathematics (Japan) $-1.53 \%$

9. Bocconi University (Italy) $-1.53 \%$

10. Columbia University (USA) $-1.53 \%$

11. University of Michigan (USA) $-1.53 \%$

\section{Economics - A2}

1. Federal Reserve System (USA) $-5.56 \%$

2. George Mason University (USA) $-2.78 \%$

3. Columbia University (USA) $-2.78 \%$

4. University of Pennsylvania (USA) $-2.78 \%$

5. University of Wisconsin (USA) $-2.78 \%$

The US dominates the academic production in QUALIS CAPES system also among the journals classified as A2, where all significant universities are from the United States. The Brazilian universities do not have significant participation among the $\mathrm{A} 1$ or $\mathrm{A} 2$ journals.

\section{BRICS}

Brazil establishes close commercial, informational and political relationship with the other countries that form the so-called BRICS (Brazil, Russia, India, China, and South Africa). In order to measure the academic relationship of these countries, the editors of institutions from China, India, Russia, and South Africa were listed.

In the A1 journals in the area of Business, Accounting and Tourism, the Chinese participation is $3.76 \%$, surpassing the participation of Brazil $(0.63 \%)$. The Indian and South African participation are, respectively, $0.53 \%$ and $0.69 \%$, percentages that are very close to the Brazilian one. The presence of editors from Russia is practically zero $(0.1 \%)$. In this area and for journals classified as A1, all BRICS countries had some participation.

In the A2 journals of the same area, only editors from China (3.38\%), India $(0.56 \%)$ and Brazil (8.47) were found.

As for Economics in A1 journals, only China and India had a $0.38 \%$ and $0.51 \%$ of the participation, respectively. As in the case of Brazil $(0.26 \%)$, the participation of these countries is not significant. Considering the A2 journals, the Chinese presence is $4.16 \%$, and South Africa and Brazil are at the same level, with a presence of $1.4 \%$ each.

\section{H-index}

Academic journals are evaluated based on the h-index developed by the Scopus database and present on the SCImago portal. The h-index expresses the number of articles $(\mathrm{H})$ that were cited at least $(\mathrm{h})$ times. The h-index allows comparing the qual- 
ity of journals in each classification and area, showing the main differences. In Business, Accounting and Tourism - A1, the average h-index or h of all journals consists of 63.4, while the median is 55 and the amplitude 151 (175-24). The index variation can be considered high, with a standard deviation of 30,23 . One of the journals was not included in the database and therefore was not registered in the SCImago portal. In the A2 classification, the mean and median values are considerably lower, being 51.27 and 38, respectively. The amplitude and standard deviation are higher, revealing even greater variation than in the previous case. The amplitude of 177 (181-4) and the standard deviation 36.685. Six journals had no classification.

In the area of Economics (for A1 publications), the results reveal the better quality of published articles compared to Business, Accounting and Tourism. The average is 81.78 , exceeding the latter by almost twenty points. The median is 71.5 and the amplitude and standard deviation, 182 (202-20) and 47,785, respectively. The high variation shows that despite the many journals with excellent results, there are several others with an average result.

The results for A2 journals in Economics are interesting. All measures are superior to the previous ones, due to the presence of the ceiling for journals from other areas of knowledge, which cannot be classified as more than A2. An example is the worldwide renowned journal Science. Its h-index is 915 and is classified A2 by the criteria established by QUALIS CAPES for Economics. The category average is 100.25 and the median is 74.5 . The variation is very high due to the presence of journals such as Science, and others of lower quality, but that are part of the area of Economics. The amplitude is 896 (915-19) and the standard deviation, 137.6.

\section{Research Content}

In order to know if the themes referring to Brazil and its problems are recurrent in the best-classified journals in the QUALIS CAPES evaluation system (observing that the presence of Brazilian editors is practically non-existent) all the articles published in the year 2016, by the five top journals of each area (Business, Accounting and Tourism; and Economics) with the highest h-indexes were listed, summing a total of 906 titles. The articles were classified according to 12 categories (an article could be classified in more than one category depending on the theme addressed). The theme of each article was established from the abstract available on the journals' website.

\section{Categories}

The twelve categories were created to identify if the articles dealt with themes considered relevant to Brazil and world. The categories are: (1) United States; (2) Europe; (3) Asia; (4) Brazil; (5) Africa; (6) Latin America; (7) BRICS; (8) Development; (9) Inequality; (10) Health; (11) Education; and (12) Theoretical.

The classifications (1) to (6) use as a criterion the fact that the article's abstract explicitly expresses dealing with countries related to one or more of the six catego- 
ries. The paper can be of any type, from comparison of the economic development between them to a model created from a country-specific problem. Although it may seem broad, the purpose of this classification is to determine the presence and importance of each region of the world for academic production in the areas of Business, Accounting and Tourism; and Economics. The rationale is that the more significant presence of articles of a region, the greater likelihood of regional specificities being represented. Finally, it is important to note that the BRICS countries, except for Brazil, were counted only in the category (7) to mark the difference between these countries and the others for this research. Brazil, being the object of analysis of the study, was considered only in the category (4), being excluded from the category BRICS (7) and Latin America (6).

The purpose of identifying the BRICS countries separately was to be able to compare the situation of Brazil with countries with similar economic development, as well as to analyze their influence in the region they are part of. The criterion is the same as the previous ones, i.e., it is considered in the category (7) if the theme was explicitly one of the countries (Russia, India, China, South Africa), disregarding the type of study carried out.

The categories Development and Inequality were created because they consist in global issues and are considered extremely important for all countries even for the most developed. Despite the relevance, it is clear that for some countries the topic is more significant than for others. It is also an objective of the classification to observe the relationship of the two categories with the categories of regional nature (one to seven) and to find out whether Development and Inequality are discussed only in developed countries or if they are considered in underdeveloped and developing countries.

For the inclusion in the category Development, the abstracts were analyzed to observe whether the theme was related to economic, social, technological development or less explicit topics, such as well-being and development of the productive process. Publications covering themes related to political systems or institutions and their strengthening were included given their influence in national development. As for the category Inequality, the criterion was the identification of topics such as income distribution (national and international), poverty and related issues, such as unemployment and child mortality.

The categories Health and Education were considered due to the relevance of the themes for Brazil. They have represented great national challenges in the last decades, regarding universalization of the services at the same time observing their quality. To be classified in the category, the articles should contain information about the health and education system, including comparisons or policy analyzes in the topics.

Finally, the category Theoretical was created to verify whether most of the articles are connected with reality or limited to theoretical models that are not connected to the world. For inclusion in the category, the article should explicitly deal with the process of creating or developing a theoretical model. 


\section{Journals}

In the area of Business, Accounting and Tourism, the following journals were analyzed: (1) Journal of Marketing; (2) Journal of International Business Studies; (3) Journal of Consumer Research; (4) Journal of the Academy of Marketing Science; (5) International Journal of Production Economics. In Economics, the following periodicals were studied: (1) The American Economic Review; (2) Econometrica; (3) Review of Financial Studies; (4) Journal of Econometrics; (5) Journal of Monetary Economics.

\section{Preliminary Analysis}

In the area of Business, Accounting and Tourism, 432 articles from the five journals with the highest h-index were listed. Of these, only five had Brazil and its particularities among the topics, which corresponds to $1.15 \%$. The category Latin America, however, was even less represented with $0.23 \%$ of the articles. The BRICS category, which analyzed the articles for China, Russia, India, and South Africa, counted 26 articles $(6 \%)$. The rankings on Asia, Europe, and Africa presented, respectively, $2.78 \%, 3.7 \%$ and $0 \%$, with no articles on Africa. The United States was explicitly mentioned in the abstract as the theme of the article in $3 \%$ of the titles analyzed for the area.

The category Development was the theme of 28 articles, with a representation of $6.48 \%$. Among all classified in the category, two were also classified in the category Brazil, and another seven were classified in the category BRICS, with 7.1\% and $25 \%$, respectively. The United States, Asia, and Europe obtained representation in the category Development of $3.5 \%, 7.1 \%$, and $7.1 \%$, respectively. The category Inequality was attributed to two articles, with $0.46 \%$ of representation.

The categories Education and Health were attributed to zero and five articles, respectively, while of the 432 articles listed 127 were put in the category Theoretical, representing $29.3 \%$ of the total. Table 1 shows how many articles are present in each category and relates the territorial and the thematic categories.

Table 1:Top 5 - A1 Business, Accounting and Tourism classified into categories

\begin{tabular}{|c|c|c|c|c|c|c|}
\hline- & Articles & Development & Inequality & Health & Education & Theoretical \\
\hline Articles & 432 & 28 & 2 & 5 & - & 127 \\
\hline USA & 13 & 1 & - & 1 & - & - \\
\hline BRICS & 26 & 7 & - & - & - & 2 \\
\hline Brazil & 5 & 2 & - & - & - & 1 \\
\hline Europe & 16 & 2 & - & - & - & 4 \\
\hline Africa & - & - & - & - & - & - \\
\hline Asia & 12 & 2 & - & - & - & 2 \\
\hline $\begin{array}{c}\text { Latin } \\
\text { America }\end{array}$ & 1 & - & - & - & - & 1 \\
\hline
\end{tabular}


In the area of Economics, the analysis was conducted on 474 articles from the five journals with the highest h-index (Table 2). Brazil was the theme in only one article $(0.21 \%)$, while Latin America was represented in $1.05 \%$. The category BRICS was attributed to 18 articles (3.8\%). Asia, Europe, and Africa, were present in $1.26 \%, 3.6 \%$ and $0.4 \%$ of the articles respectively. Different from the area of Administration, Accounting, and Tourism, a high number of articles (56) were in the category United States, representing $11.8 \%$.

The category Development was found in 52 articles (10.9\%). None of these 52 articles also refers to Brazil, six of them refer to BRICS, and 16 are related to the United States (30.7\%). Asia, Europe, and Africa have 1.9\%, 7.7\% and 1.9\% of the articles classified in the category Development. As for the category Inequality, it counted 29 articles, of which six are linked to the United States and four to BRICS. Asia, Africa, and Europe have only one article related to Inequality.

The categories Health and Education presented eleven and seven articles, respectively, and the Brazilian problems were more represented in the area of Economics than in the area of Administration, Accounting, and Tourism. Of the 474 articles, 232 were classified in the category Theoretical (48.9\%).

Table 2: Top 5 - A1 Economics classified into categories

\begin{tabular}{|c|c|c|c|c|c|c|}
\hline & Articles & Development & Inequality & Health & Education & Theoretical \\
\hline Articles & 474 & 52 & 29 & 11 & 7 & 232 \\
\hline USA & 56 & 16 & 6 & 1 & 3 & 14 \\
\hline BRICS & 18 & 6 & 4 & 1 & 1 & 4 \\
\hline Brazil & 1 & - & - & - & - & - \\
\hline Europe & 17 & 4 & 1 & 1 & 1 & 5 \\
\hline Africa & 2 & 1 & 1 & - & - & - \\
\hline Asia & 6 & 1 & 1 & - & - & 2 \\
\hline Latin America & 5 & 3 & - & - & 1 & 1 \\
\hline
\end{tabular}

Analyzing the results by the journal, separately, it is possible to observe a greater representation of Brazil in the International Journal of Production Economics with three articles about the country. This journal also presents four articles on Health and 16 on Development. Another relevant journal regarding the presence of Brazil and the country's issues of interest is the American Economic Review with 21 articles on Development, 15 on Inequality, five on Education and eight on Health. The journal, however, focuses on the United States with 18 articles, and one on Brazil. 


\section{IS HEGEMONY ONLY REFLECTING ECONOMIC POWER?}

When seeking to understand the reason for the predominance of some countries as we observed throughout this study, we listed two factors that may potentially influence the number of editors and high-quality journals. One factor would be the per capita income, which would indicate that economic development and wealth of a nation influence the number of editors and journals originated in a country. Another factor consists of the population, indicating that the number of inhabitants in a country would result in the emergence of more or fewer people with the capacity to become editors or if the external stimulus is needed to achieve such a condition (World Bank, 2016).

Analyzing the per capita income relation with the number of editors, a moderate correlation of 0.5742 was found. This represents that the factor income has little influence in the condition of having more presence in the editorial boards. As for the influence of the population size, we did not find any correlation (-0.1725). Chart 9 shows that a moderate correlation found between the presence in the editorial boards and income is observed in the United States, but not in the other countries analyzed.

Chart 9: Presence in editorial boards vs. per capita income (US\$)

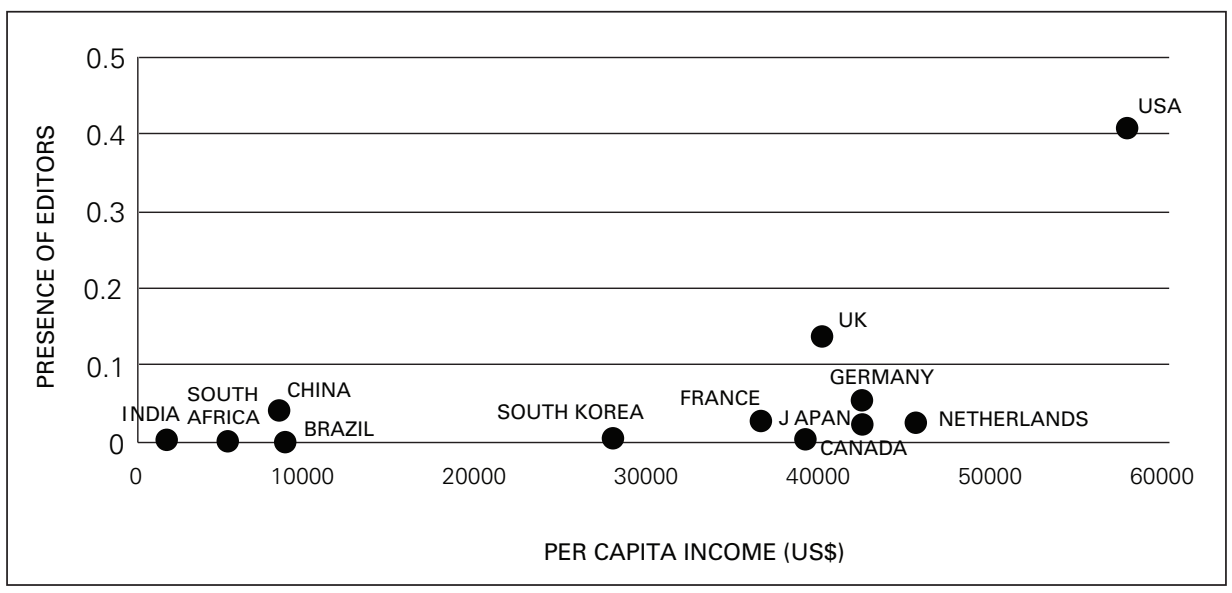

About the frequency of journals, similar results were obtained with little influence of per capita income, presenting a correlation of 0.4809 , and no influence of the population, presenting a correlation of -0.1701 .

As a first observation, it is essential to highlight that the BRICS countries, including Brazil, in this case, are generally more important to the academic landscape than the region where the country is located (such as the case of Brazil in Latin America). Although the category BRICS does not make the distinction, it is worth questioning if all countries are the target of research works or only China attracts the academic interest due to its increased global importance in recent decades. 
As for the United States, who had an exorbitant dominance in the control of editorial boards, such dominance over the topic of articles to be published is clear in the area of Economics. In the area of Administration, Accounting, and Tourism, however, the hegemony is not as clear, although it still exists. The predominance of the Americans is observed when analyzing the category Development, where 17 articles related to the US were found, (of a total of 80 ). For the category Inequality, we found six articles of the 31 published. It should be noted that even though there are 80 articles on Development, most are not associated with countries, which is even more significant considering that the United States is associated with 17 of them. The same applies to the category Inequality. Another factor to consider is that the country may not be mentioned in the abstract. This means that some of the articles - even though dealing with issues related to the United States as their main subject - may have been misplaced in categories because they mention the US in their abstracts. Also, it is possible that articles mention the US to attract readers but in fact are dealing with other countries.

The categories Education and Health do not seem to be of great importance in the academic landscape studied. The greater presence of the second, with 11 articles in both areas, appears to occur because the health system is also a North American problem.

Although still underrepresented, Brazil has greater influence than entire regions of the globe such as Asia, Latin America, and Africa, with an emphasis on the latter that had only two articles published out of the 906 listed. Despite this, the United States, Europe, and their challenges continue with considerably greater representation, with a small, yet existing space for Brazilian affairs.

It is essential to stress that the condition reached by the United States and the United Kingdom is not exclusive to their development and economic growth, other factors influence their hegemony and give them the condition of dictating what is and is not science in these areas. The emergence of scholars is not subject to chance, and Brazil needs to find out what elements are indispensable for the consolidation of an environment in which the emergence of scholars with international relevance becomes common.

\section{CONCLUSION}

Results show the USA and the United Kingdom have an overwhelming dominance in the editorial landscape for A1 journals. Other countries including Brazil do not have significant participation. The hegemony of these two countries is not restricted to the editorial boards, but also concerns the journals' country of origin. In the context in which there are no Brazilian journals classified as A1 by QUALIS CAPES system, there are, as a consequence, few Brazilian editors among the listed in this research related to educational institutions of the country. The number of Brazilian editors is restricted to few scholars related to national universities that are highly integrated internationally. Other countries with increasing relevance in 
the international economic scenario, such as the so-called BRICS, also did not guarantee their space in the editorial boards.

The question to be answered is whether the situation arises from an international context where the only thing Brazil can do is to provide the mechanisms for Brazilian institutions to integrate internationally. The other possibility is that the scenario was created by Brazil because of the lack of valorization of local scientific production and the focus on international indicators, always giving priority to what comes from abroad. The fact that the area of Economics adopts different ceilings to journals that come originally from other areas is the perfect example of the situation, with a ceiling of "A1" for international journals, and another, "A2", for the national publications. Such a difference appears to be based on prejudice against Brazilian production. In practical terms, national topics are more irrelevant than research topics that can be embedded or compared to the US context, for example, which is a dangerous bias for national research.

Regarding the publications, one can conclude that there is space for Brazil and China to be the object of study since they are countries with notorious development in the last decades. However, such space appears to be the fruit of the current economic conditions and the importance of their transactions with the rest of the world, mainly the United States and the United Kingdom. The Brazilian relevance seems to be circumstantial, related to its importance for the hegemonic countries, which is a fragile space for academic publications.

The objective of this study when presenting the presence of Brazil in the academic landscape is to encourage further studies to answer the question: what are the solutions for the country to achieve meaningful representation in editorial boards, at the same time as conquering a consolidated space as a topic in articles published in the high-level journals? Economic development and high per capita income have proved to be insufficient, requiring the country to go deeper in the quest for alternatives to increase its influence and relevance in the academia.

The initial impressions to be highlighted is that the solution to the problem lies much more in internal than external aspects, and it is essential that agencies such as CAPES give more importance to national affairs, valuing in their classification the journals that focus on Brazil. The case of the Brazilian Journal of Public Administration (RAP), which obtained a higher category given its relevance and uniqueness, is an excellent example of the way forward. When there is greater recognition for articles focusing on issues of the country's interest, greater are the incentives to develop solutions to the country's challenges, as opposed to the current situation where solutions created for external problems are copied and applied in Brazil.

Another important point is to understand how some Brazilian institutions managed to break the international barrier and be recognized worldwide, such as FGV and the Oswaldo Cruz Foundation, which obtained significant editorial representation in journals of the area of Business, Accounting and Tourism, classified as $\mathrm{A} 2$.

Finally, this study shows how the prejudices with the national academic pro- 
duction, as observed in the area of Economics, are symptoms of the daily devaluation of what is produced internally, covering the academic and other sectors. The low external acceptance may result from the lack of recognition of Brazilian production by Brazilians themselves.

\section{REFERENCES}

AEA. (2017) By-Laws of The American Economic Association (AEA). Available at: <https://www. aeaweb.org/about-aea/bylaws>. Accessed on June 21, 2017.

AMA. (2017) Journal of Marketing. Available at: <https:/www.ama.org/publications/JournalOfMarketing/Pages/About.aspx>. Accessed on June 21, 2017.

Almeida, Francisco Ribeiro de. (2010) Revistas acadêmicas de administração: proposição de ampliação de escopo. Tese de Doutorado em Administração, Faculdade de Economia, Administração e Contabilidade, Universidade de São Paulo, São Paulo. doi:10.11606/T.12.2010.tde05052010-121828. Accessed on September 21, 2016.

Bertero, Carlos Osmar et al. (2013) "Produção científica brasileira em administração na década de 2000”. Revista de Administração de Empresas, São Paulo, v. 53, n. 1, p. 12-20. Available at: $<$ http://www.scielo.br/scielo.php?script=sci_arttext \&pid=S0034-75902013000100002\&lng=e n\&nrm=iso>. Accessed on September 18, 2016. http://dx.doi.org/10.1590/S003475902013000100002 .

CAPES. Critérios de Classificação QUALIS - Ensino. São Paulo. Available at: <http://www.biblioteca. ics.ufpa.br/arquivos/QUALIS-rev_26_11.pdf>. Accessed on October 13, 2016.

CAPES. (2015) Relatório do processo de classificação de periódicos - Área de Administração, Ciências Contábeis e Turismo. Available at: <https://www.capes.gov.br/images/stories/download/ avaliacaotrienal/Docs_de_area/qualis/administracao_ciencias_contabeis_e_turismo.pdf $>$ Accessed on October 26, 2016.

CAPES. (2014) Sobre a Avaliação. Brasília, 21 de Maio de 2014. Available at: <http://www.capes.gov. br/avaliacao/sobre-a-avaliacao>. Accessed on October 26, 2016.

Combes, Pierre-Philippe and Linnemer, Laurent. (2010) Inferring Missing Citations: A Quantitative MultiCriteria Ranking of all Journals in Economics. Available at: < https://hal.inria.fr/halshs-00520325/PDF/DTGREQAM2010-28.pdf>

Econometric Society. About. Available at: <https://www.econometricsociety.org/society/about>. Accessed on June 21, 2017.

Elsevier. Content Policy and Selection. Available at: <https:/www.elsevier.com/solutions/scopus/content/content-policy-and-selection>. Accessed on October 13, 2016.

Elsevier. International Journal od Production Economics. Available at: <https://www.journals.elsevier.com/international-journal-of-production-economics/>. Accessed, June 21, 2017.

Elsevier. Journal of Econometrics. Available at: <https://www.journals.elsevier.com/journal-of-econometrics/>. Accessed on June 21, 2017.

Elsevier. Journal of Monetary Economics. Available at: <https://www.journals.elsevier.com/journal-of-monetary-economics/>. Accessed on June 21, 2017.

Elsevier (2014). The Scopus h-index, what's it all about? Part I. Available at:<https://blog.scopus. com/posts/the-scopus-h-index-what-s-it-all-about-part-i> Accessed on October 26, 2016.

Fadul, Élvia et al. (2014) “Administração pública no Brasil: reflexões sobre o campo de saber a partir da Divisão Acadêmica da Associação Nacional de Pós-Graduação e Pesquisa em Administração (2009-2013)". Revista de Administração Pública, Rio de Janeiro , v. 48, n. 5, p. 1329 1354.. Available at: <http://www.scielo.br/scielo.php?script=sci_arttext\&pid=S0034 -76122014000500012\&lng=en\&nrm=iso>. Accessed on September 18, 2016. http://dx.doi. org/10.1590/0034-76122012 
Fausto, Sibele de. JCR (2016) “2015 tem novidades: mais revistas brasileiras indexadas". Available at: <http://www.sibi.usp.br/?p=5938>. Accessed on October 18, 2016.

ISI. Selection Criteria. Available at: <http://isindexing.com/isi/selection.php >. Accessed on October $13,2016$.

ISI. About Us. 2016. Available at: <http://isindexing.com/isi/aboutus.php>. Accessed on October 13, 2016.

ISSN. The ISSN International Register, an incomparable working tool. Available at: <http://www.issn. org/services/subscribe-to-the-register/the-issn-international-register-an-incomparable-working-tool/>. Accessed on October 13, 2016.

JAMS. Journal of Academic Marketing Science. Available at: <http://www.springer.com/ business+\%26+management/journal/11747>. Accessed on June 21, 2017.

JCR. About the Journal. Available at: <https://academic.oup.com/jcr/pages/About>. Accessed 21, 2017.

JIBS. Journal of International Business Studies. Available at: <http://www.jibs.net/>. Accessed June 21, 2017.

Pacheco, Regina Silvia (2003).”Administração pública nas revistas especializadas: Brasil, 19952002”. Revista de Administração de Empresas., São Paulo, v. 43, n. 4, p. 63-71. Available at: $<$ http://www.scielo.br/scielo.php?script=sci_arttext\&pid=S0034-75902003000400005\&lng=e $\mathrm{n} \& \mathrm{nrm}=\mathrm{iso}>$. Accessed on September 18, 2016. http://dx.doi.org/10.1590/S003475902003000400005 .

Passos, Mariana de Aquino. (2011) O portal de revistas científicas da CAPES: seu uso por pesquisadores de ciências humanas da USP. Dissertação de Mestrado em Interfaces Sociais da Comunicação, Escola de Comunicações e Artes, Universidade de São Paulo, São Paulo. doi:10.11606/D.27.2011.tde-23092011-201528. Accessed on September 28, 2016.

Pereira, Glaucia Guimarães. (2005) Avaliação da CAPES: abordagem quantitativa multivariada dos programas de administração. Dissertação de Mestrado em Administração, Faculdade de Economia, Administração e Contabilidade, Universidade de São Paulo, São Paulo. doi:10.11606/D.12.2005.tde-25092007-004335. Accessed on October 05, 2016.

Thomson Reuters. See how to identify top performing journals. 2016. Available at: <http://ipscience. thomsonreuters.com/product/journal-citation-reports/>. Accessed on October 13, 2016.

Thomson Reuters. The Thomson Reuters Journal Selection Process. 2016. Available at: <http:// wokinfo.com/essays/journal-selection-process/>. Accessed on October 18, 2016.

Review of Financial Studies. About the Journal. Available at: <https://academic.oup.com/rfs/pages/ About>. Accessed on June 21, 2017.

World Bank. GDP per Capita (current US\$). Available at: <http://data.worldbank.org/indicator/ NY.GDP.PCAP.CD>. Accessed on July 16, 2017.

World Bank. Population, total. Available at: <http://data.worldbank.org/indicator/SP.POP.TOTL>. Accessed on July 16, 2017. 